\title{
Indiginasi Seni dan Budaya dalam Pembelajaran Fisika
}

\author{
Mujadi \\ Pendidikan Fisika Universitas Terbuka Jakarta \\ J1. Cabe Raya, Pondok Cabe, Pamulang, Banten I54I8, Indonesia \\ Surat-e: trimurtadi@gmail.com
}

\begin{abstract}
"Pelajaran apa yang paling sulit dan tidak anda sukai?" Pertanyaan tersebut oleh siswa-siswa SMP maupun SMA akan dijawab dengan pasti, yaitu "pelajaran matematika, fisika, dan kimia". Diantara ketiga pelajaran tersebut pelajaran Fisika sudah pasti menjadi monster yang menakutkan bagi para siswa di SMP maupun di SMA. Meng-Indiginasi Seni dan Budaya dalam Pembelajaran Fisika di sekolah sangat menyenangkan adalah suatu kesatuan ilmu yang satu dengan lainnya saling berkorelasi. Seni dan budaya yang ada di Nusantara ini sebaiknya tidak hanya dipandang dari sisi keindahannya saja, namun masih ada yang tersembunyi dibalik keindahan itu adalah ilmu pengatahuan dan teknologi. Kegiatan-kegiatan seni dan budaya banyak di aktualisasikan dalam bentuk simbol-simbol yang statis maupun dinamis seperti taritarian dan bangunan-bangunan candi. Suatu uji coba bagaimana mengawali siswa belajar fisika menjadi menyenangkan bukan dari rumus-rumus dan hitungan-hitungan yang cukup menyulitkan bagi siswa, atau melalui motivasi dan apersepsi yang terfokus pada pelajaran fisika yang membuat siswa dari awal sudah diajak berpikir keras. Pelibatan seni dan budaya memungkinkan siswa tanpa disadari telah diajak belajar fisika. Pada proses ini siswa tidak merasakan sama sekali bahwa apa yang dilihatnya akan membuka cakrawala berpikir dengan mudah dan menyenangkan. Dari beberapa uji coba dibeberapa siswa SMA maupun SMP diperoleh data bahwa Seni dan Budaya dapat memberi sumbangan yang sangat besar dan menyenangkan bagi siswa untuk mengawali pembelajaran fisika.
\end{abstract}

Kata kunci: Indiginasi; Seni, dan Budaya

\section{Latar Belakang}

Beberapa cara pada proses pembelajaran Fisika di SMP maupun di SMA untuk menjadikan mata pelajaran Fisika itu menarik dan menyenangkan masih banyak mengalami hambatan yang pada akhirnya menjadikannya pelajaran fisika itu tetap mendapatkan julukan yang beragam diantaranya; sangat sulit, menakutkan, dan dihindari banyak siswa. Suatu perbandingan yang cukup mengesankan misalnya di SMA kelas X, jumlah kelas IPA dan IPS bisa mencapai I : 2 , bahkan lebih besar lagi.

Sungguh sangat mencengangkan apa yang dikatakan banyak siswa sekolah menengah pertama maupun sekolah menengah atas tentang pelajaran fisika di sekolah?. Suatu pernyataan yang jujur terlontar dari para siswa bagaimana ketidak sukaan terhadap pelajaran fisika, bahkan ketidak sukaan tersebut tidak sedikit mengarah pada guru fisikanya. Cukup lengkap kiranya jika pada akhirnya nanti prosentase ketidak sukaan siswa pada pelajaran fisika semakin menebal dan menjadi satu-satunya pelajaran dengan predikat "tidak menyenangkan". Berikut merupakan pernyataan siswa yang terekam dari beberapa sekolah SMP, SMA, dan bimbingan belajar yang ada di daerah Jakarta Selatan tanpa harus mendatangi sekolah.
Adapun rekaman-rekaman tersebut didapat dengan cara bertanya secara tidak langsung dalam situasi penuh akrab dan suasana sangat santai, antara lain:

I. Fisika itu sangat sulit.

2. Fisika sangat membosankan.

3. Fisika sangat banyak hitungannya

4. Fisika bukunya tidak menarik untuk dipelajari

5. Fisika sangat membingungkan.

6. Fisika diperlukan penalaran.

7. Fisika harus pintar berhitung.

8. Fisika gurunya rata-rata jahat.

9. Fisika gurunya tidak bisa senyum.

I0. Fisika tidak menyenangkan

II. Fisika diperlukan praktikum dilaboratorium.

I2. Fisika sangat menakutkan.

I3. Fisika belajar tidak santai.

I4. Fisika sangat menegangkan.

15. Fisika itu tidak berguna.

I6. Fisika sebaiknya tidak ikut Ebtanas.

17. Fisika perlu imajinasi

I8. Fisika membuat malas berpikir

19. Fisika pelajaran aneh

20. Fisika merusak fisik

2I. Fisika hanya untuk IQ tinggi 
22. Fisika gurunya harus menyenangkan

23. Fisika gurunya harus kreatif dan inovatif

24. Fisika gurunya harus mengerti kesulitan

25. Fisika gurunya harus seorang motivator

26. Fisika itu harus mudah dipelajari.

Tidak semua hambatan dalam proses pembelajaran fisika terfokus pada guru, banyak faktor yang mendukungnya, salah satu diantaranya adalah laboratorium yang lengkap. Kelengkapan laboratorium ini harus dibarengi dengan kegiatan siswa sehingga ada keterampilan-keterampilan yang terbina dari awal untuk dapat berkembang menjadi bentuk inovasi-inovasi baru. Kegiatan laboratorium yang teratur akan senantiasa membawa siswa dihadapkan pada fenomena baru dan timbulnya tantangan untuk mencoba membuat karya karsa dan cipta. Memaksakan siswa untuk menyenangi fisika bukanlah tindakan yang baik dan adil, namun menunjukkan pada siswa bahwa fisika itu sangat mnyenangkan memberikan pilihan pada siswa untuk mengatakan bahwa fisika itu memang sangat menyenang. Menyenangkan mempunyai makna bahwa dari awal siswa tidak perlu secara langsung diberikan materi pelajaran fisika yang penuh dengan hukum-hukum, rumus-rumus, dan hitungan. Banyak cara yang mungkin memudahkan belajar fisika, satu diantaranya indiginasi seni dan budaya yang dilibatkan untuk membuka dan menghantarkan siswa bahwa fisika itu menyenangkan dan mudah. Melibatkan seni dan budaya terasa aneh pada awalnya, namun setelah mengetahui apa yang dilihatnya adalah sangat erat kaitannya dengan fenomena pembelajran fisika, maka secara tidak sadar siswa telah diajak bersama menganalisis gerakan-gerakan seni yang ada adalah gambaran dari peristiwa fisika.

\section{Masalah}

Seni dan budaya yang ada di nusantara ini sangatlah beragam. Seni jangan hanya dipandang dari segi keindahannya saja, sebaliknya budaya yang ada di bumi nusantara sangatlah banyak dan beragam janganlah dianggap berdiri sendiri. Jika ini terjadi maka ilmu pengetahuan akan kehilangan mata rantai. Semua ilmu yang ada di dunia ini adalah suatu mata rantai yang satu dengan lainnya saling mengikat dan saling berkontribusi satu dengan lainnya. Dalam proses pembelajaran khususnya di sekolah-sekolah perlu dipastikan adanya keterpaduan antara pelajaran satu dengan lainnya. Jika masalah ini digali dan dikembangkan, maka hambatan pembalajaran yang ada akan dapat dihilangkan. Benarkah indiginasi seni dan budaya dapat memberi arti yang monumental dan diterima siswa sangat menyenangkan?

\section{Tujuan}

Sebagaimana telah diuraiakan diatas hambatan pembelajaran IPA-Fisika di sekolah-sekolah bukan hal yang baru bagi guru maupun siswa. Satu sisi guru selalu berusaha melalui berbagai metode, teknik, dan pendekatan mengajar fisika agar siswa mampu, sebaliknya siswa demikian juga dalam pemebelajaran fisika menganggap sebagai beban yang sangat berat. Indiginasi seni dan budaya terhadap pembelajaran Fisika dalam proses pembelajaran di sekolah- sekolah bertujuan:

I. Membangkitkan rasa ingin tahu siswa dengan mempertanyakan fenomena alam atau penerapan teknologi (animasi/dry lab) seni dan budaya yang erat kaitannya dengan materi fisika

2. Memotivasi guru fisika untuk lebih kreatif dan inovatif dalam proses pembelajaran fisika memanfaatkan seni dan budaya lokal maupun seni modern .

\section{Pengertian Indiginasi}

Kesenian sebagai salah satu unsur kebudayaan[I] pada dasarnya merupakan produk budaya masyarakat yang melukiskan penghayatan tentang nilai yang berkembang dalam lingkungan masyarakat pada masing-masing jamannya. Berkaitan dengan nilai-nilai dalam masyarakat, dewasa ini telah mulai dikembangkan proses "indiginasi", yakni pemanfaatan kebudayaan daerah untuk pembelajaran mata pelajaran lain dengan tujuan untuk mendekatkan pelajaran itu dengan lingkungan sekitar siswa, agar hasil belajar lebih bermakna sebagai wahana pengembangan watak individu sebagai warganegara. Contohnya, legenda dari seluruh penjuru tanah air seperti Malin Kundang dari Sumatra Barat, dan Sangkuriang dari Jawa Barat, digunakan sebagai stimulus dalam pembahasan suatu konsep nilai atau moral surga ada di telapak kaki ibu. Dalam konteks Pendidikan Ilmu Pengetahuan Sosial dan Pendidikan Kewarganegaraan, yang merupakan mata pelajaran yang sarat dengan nilai sosial, pendidikan nilai mencakup substansi dan proses pengembangan nilai patriotisme seperti cinta tanah air, hormat pada para pahlawan yang sengaja dikemas untuk melahirkan individu sebagai warganegara yang cerdas dan baik, rela berkorban untuk bangsa dan negara. Walaupun masa itu konteksnya masih terbatas pada ilmu-ilmu sosial, maka dengan perkembangan pola pikir yang konstruktif indiginasi seni dan budaya mampu mengkaitkan dengan Ilmu Pengetahuan Alam (IPA).

Indiginasi dapat juga dimanfaatkan sebagai salah satu alternatif pembelajaran IPA-Fisika dan lainnya sebagai motivasi awal yang menjadikan siswa/mahasiswa tertarik dan menyenangkan untuk belajar IPA-Fisika. Sebagai contoh; untuk mempelajari keseimbangan benda tegar maupun gaya-gaya pada suatu benda, atau hukum Newton, siswa/mahasiswa akan mengalami banyak 
hambatan dan kesulitan jika diberikan secara langsung tanpa mengawali dari kejadian-kejadian yang ada di lingkungan. Seni tari Sisingaan dari Jawa Barat dan tari tari Lawung dari Jawa Tengah merupakan salah satu contoh yang perlu diperkenankan pada awal proses pembelajaran fisika. Masih banyak contoh seni yang dapat memberikan kontribusi proses pembelajaran yang kasat mata dan menyenangkan.

Indiginasi seni dalam pembelajaran IPA dapat juga berasal dari hasil ciptaan teknologi modern seperti animasi yang dihasilkan dari computer yang merekam bagian yang ada pada konsep-konsep IPA secara lengkap dan jelas. Bahkan hitungan secara matematika dalam konsep fisika dapat langsung terekam dan dicari hasilnya. Sehingga nilai-nilai kearifan lokal akan semakin melengkapi proses pembelajaran yang beragam dan lebih kaya inovasi.

\section{Pengertian Seni}

\section{Pengertian Seni Menurut Ki hajar Dewantara Dan Para Ahli}

Ada beberapa pengertian seni menurut beberapa para ahli. Salah satunya adalah menurut Ki Hajar Dewantara. Menurut Ki Hajar Dewantara Seni adalah segala perbuatan manusia yang timbul dari perasaan dan sifat indah, sehingga menggerakan jiwa perasaan manusia. Pada awalnya Seni adalah proses dari manusia, Seni yang berisi keindahan dan keunikan yang dimiliki oleh manusia yang berasal dari pikiranya. Dewasa ini, seni bisa dilihat dalam intisari ekspresi dari kreativitas manusia. Seni juga dapat diartikan dengan sesuatu yang diciptakan manusia yang mengandung unsur keindahan.Seni sangat sulit untuk dijelaskan dan juga sulit dinilai dengan materi. Bahwa masing-masing individu memilih sendiri peraturan dan ukuran yang menuntunnya atau kerjanya, masih bisa dikatakan bahwa seni adalah proses dan produk dari memilih medium, dan suatu set peraturan untuk penggunaan medium itu.

Ada macam-macam karya seni, antara lain seni lukis, seni gerak, seni suara dan lain sebagainya. Selain menurut Ki Hajar Dewantara banyak para ahli yang memberikan pengertian Seni, antara lain:

I. Aristoteles: Seni adalah peniruan terhadap alam tetapi sifatnya harus ideal.

2. Plato dan Rousseau: Seni adalah hasil peniruan alam dengan segala seginya.

3. Ahdian Karta Miharja: Seni adalah kegiatan rohani yang mereflesikan realitas dalam suatu karya yang bentuk dan isinya mempunya untuk membangkitkan pengalaman tertentu dalam rohaninya penerimanya.

4. Drs. Sudarmaji, Seni adalah segala manifestasi batin dan pengalaman estetis dengan menggunakan media bidang,garis, warna,tekstur,volume dan gelap terang.
5. Drs Popo Iskandar: Seni adalah hasil ungkapan emosi yang ingin di sampaikan kepada orang lain dalam kesadaran hidup bermasyarakat/berkelompok.

6. Prof. Drs. Suwaji bastomi: Seni adalah aktivitas batin dengan pengalaman estetika yang menyatakan dalam bentuk agung yang mempunyai daya membangkitkan rasa takjub dan haru.

7. Enslikopedia Indonesia: Seni adalah penciptaan segala hal atau benda yang karena keindahannya orang senang melihatnya atau mendengarnya.

8. Schopenhauer: Seni adalah segala usaha untuk menciptakan bentuk-bentuk yang menyenangkan. Menurut tiap orang senang dengan seni music meskipun seni musik adalah seni yang paling abstrak

9. J. Eric Ariyanto: Seni adalah kegiatan rohani atau aktivitas batin yang di refleksikan dalam bentuk karya yang dapat membangkitkan perasaan orang lain yang melihat atau mendengarkannya.[2]

\section{Pengertian Budaya Menurut para Ahli}

Indonesia dengan semua propinsi yang ada masingmasing mempunyai budaya sendiri. Kata budaya diambil dari bahasa sansekerta yaitu buddhayah yang mempunyai arti bahwa segala sesuatu yang ada hubungannya dengan akal dan budi manusia. Secara harfiah, budaya ialah cara hidup yang dimiliki sekelompok masyarakat yang diwariskan secara turun temurun kepada generasi berikutnya. Adapun perbedaan antara agama, suku, politik, pakaian, lagu, bahasa, bangunan, maupun karya seni itu akan membuat terbentuknya suatu budaya.

I. Soelaiman Soemardi \& Selo Soemardjan menerangkan bahwa suatu kebudayaan merupakan buah atau hasil karya cipta \& rasa masyarakat. Suatu kebudayaan memang mempunyai hubungan yang amat erat dengan perkembangan yang ada di masyarakat. Seorang arkeolog, R. Seokmono menerangkan bahwa budaya adalah hasil kerja atau usaha manusia yang berupa benda maupun hasil buah pemikiran manusia dimasa hidupnya.

2. Lehman, Himstreet, dan Batty mendefinisikan budaya sebagai kumpulan beberapa pengalaman hidup yang ada pada sekelompok masyarakat tertentu. Pengalaman hidup yang dimaksud bisa berupa kepercayaan, perilaku, \& gaya hidup suatu masyarakat.

Budaya yang ada di Indonesia amat berpengaruh pada perkembangan jaman dari masa ke masa \& berubahnya kondisi alam yang ada di Indonesia. Hal tersebut sangat sesuai dengan pendapat seorang pakar dari Indonesia yaitu Ki Hajar Dewantara, yang memaparkan bahwa budaya adalah hasil perjuangan masyarakat terhadap alam \& zaman yang membuktikan kemakmuran $\&$ kejayaan hidup 
masyarakat dalam menyikapi atau menghadapi kesulitan \& rintangan untuk mencapai kemakmuran, keselamatan dan kebahagiaan di hidupnya. Ada beberapa penjelasan budaya lainnya menurut para ahli salah satu diantaranya adalah :

Menurut Koentjaraningrat: Budaya merupakan sebuah sistem gagasan \& rasa, sebuah tindakan serta karya yang dihasilkan oleh manusia didalam kehidupannya yang bermasyarakat, yang dijadikan kepunyaannya dengan belajar[3].

\section{Seni dan Budaya}

Pengertian Seni Budaya adalah suatu segala sesuatu yang diciptakan manusia mengenai cara hidup berkembang secara bersama pada suatu kelompok yang mengandung unsur keindahan (estetika) secara turun temurun dari generasi ke generasi. Beberapa pendapat tentang seni budaya, diantaranya:

I. Harry Sulastianto

Seni budaya merupakan suatu keahlian mengekspresikan ide-ide dan pemikiran estetika, termasuk mewujudkan kemampuan serta imajinasi pandangan akan benda, suasana, atau karya yang mampu menimbulkan rasa indah sehingga menciptakan peradaban yang lebih maju

2. M. Thoyibi

Seni budaya merupakan penjelmaan rasa seni yang sudah membudaya, yang termasuk dalam aspek kebudayaan, sudah dapat dirasakan oleh orang banyak dalam rentang perjalanan sejarah peradaban manusia.

3. Sartono Kartodirdjo

Seni budaya merupakan sistem yang koheren karena seni budaya dapat menjalankan komunikasi efektif, antara lain dengan melalui satu bagian saja dapat menunjukkan keseluruhannya [4]

\section{Macam-macam Teori Belajar}

Ada tiga kategori utama atau kerangka filosofis mengenai teori-teori belajar, yaitu: teori belajar behaviorisme, teori belajar kognitivisme, dan teori belajar konstruktivisme. Teori belajar behaviorisme hanya berfokus pada aspek objektif diamati pembelajaran. Teori kognitif melihat melampaui perilaku untuk menjelaskan pembelajaran berbasis otak.

Peneliti kelompok Artvision percaya bahwa pendekatan tersebut memiliki potensi yang luar biasa bagi sekolah untuk menjawab tantangan terhadap peningkatan kualitas lulusannya dari sisi intelektual maupun afektif. Selain itu, Elster (200I), dan Grauer, et.al. (200I) juga menjelaskan bahwa telah banyak tulisan yang membahas tentang nilai seni dan budaya untuk meningkatkan kreativitas siswa, serta nilai seni dan budaya dalam mengembangkan berbagai keterampilan dan konsep pengetahuan lainnya. Sementara itu, Goldberg (200I) dari Amerika Serikat, melalui penelitiannya di daerah multi budaya Escundido California mengintegrasikan seni dan budaya Indian, Cina, dan Meksiko kedalam berbagaimata pelajaran. Hasil penelitian Goldberg mengkonfirmasi bahwa: arts are powerful tools for motivating students to apply their knowledge,work cooperatively,and make connections across content areas. Artsintegration can become a natural tool of everyday learning. At the same time, it challenges teachers and educators to be able to collaborate with artists and students, and to teach creatively.

Di Filipina, upaya integrasi seni dan budaya dalam pembelajaran telah dilakukan oleh Rapanut, et. al.(I996) yang menggunakan pendekatan ethnomathematics untuk meneliti berbagai operasi matematika dari beberapa aspek seni dan budaya masyarakat Kankana-ey di Mountain Province. Hasil penelitian tersebut diwujudkan dalam bentuk serangkaian rencana pembelajaran matematika untuk siswa sekolah menengah tahun pertama. Upaya lain yang dilakukan di Filipina adalah penerbitan berbagai publikasi yang memandu guru matematika dan IPA dalam mengintegrasikan seni dan budaya dalam pembelajarannya. Publikasi tersebut antara lain:

"Philippine Folk Science (Katutubong Agham ng Pilipina s),Paper Folding: Art and Mathematics, Science and Math ematics Stories,Science and Mathematics of Toys". (NIS MED,200I).

\section{Belajar Fisika dengan Mudah}

Banyak cara yang dilakukan oleh guru fisika agar materi yang disajikan menarik, menyenangkan, dan tidak membosankan untuk diterima oleh siswa. Lebih utama lagi bahwa materi tersebut tidak memberi kesan bahwa fisika itu sulit tetapi mudah untuk dipelajari dan menyenangkan. Ada beberapa teknik, ide, maupun cara mudah pembelajaran fisika di sekolah, diantaranya;

\section{Kesan pertama itu Menentukan}

Alangkah baiknya jika kita mengawali pembelajaran fisika, baik secara langsung (di kelas) maupun secara tidak langsung (melalui tulisan, seperti yang dilakukan para guru) dengan hal-hal yang menyenangkan, jangan belum apa-apa sudah dikasih rumus, latihan soal yang akhirnya siswa bisa dibuat langsung lemas tak berdaya, rumus lagi rumus lagi, mungkin mereka tampak serius mendengarkan kita, tapi dalam hati mereka mungkin jengkel, tidak senang sama gurunya atau malah tidak perduli lagi.

\section{Memancing Rasa Penasaran dan Ingin Tahu}

Alangkah baiknya jika kita manfaatkan sebaik-baiknya salah satu kelemahan dan kekuatan manusia ini dalam pembelajaran fisika. Kalau pembelajaran dilakukan secara langsung (di kelas), sebaiknya diterapkan pada awal pembelajaran. Pada dasarnya ilmu fisika itu dekat dengan kehidupan kita. Karenanya membangkitkan rasa ingin tahu siswa dengan mempertanyakan fenomena alam atau 
penerapan teknologi yang punya kaitan dengan materi yang dipelajari membuat siswa penasaran.

\section{Gunakan bahasa yang Sederhana}

Gunakan bahasa yang sederhana dalam setiap pembelajaran, jangan gunakan bahasa yang "tinggi", implementasi, analogi, eksistensi dan seterusnya sebaiknya ditiadakan, serahkan saja urusan bahasa kepada guru bahasa Indonesia.

\section{Penurunan Rumus Harus Terperinci}

Mempejari fisika tidak pernah lepas dari rumus-rumus yang ada di dalamnya. Tahapan penurunan rumus harus dipaparkan secara jelas dan mudah, setelah A, lanjut ke B, setelah B lanjut ke C. setelah C, lanjut ke D, dan seterusnya. Jangan setelah C langsung ke F, kalau siswa yang daya tangkapnya cepat bisa langsung paham, tapi bagi siswa yang daya tangkapnya tidak terlalu cepat akan melemahkan motivasi siswa itu sendiri. Proses alamiah ini sebaiknya kita gunakan juga dalam pembelajaran fisika di kelas, berikan contoh soal yang mudah dulu, baru soal yang sedang selanjutnya ke sulit.

\section{Konsep Fisika dalam Seni dan Budaya}

Di bawah ini macam seni dan budaya lokal maupun modern yang memungkinkan dapat berkontribusi untuk dijadikan sebagai motivasi siswa dalam belajar fisika di sekolah.

Tabel I. Tabulasi Indiginasi Seni dan Budaya dalam Konsep Dasar Fisika

\begin{tabular}{|c|c|c|}
\hline No & $\begin{array}{c}\text { Konsep-konsep Fisika } \\
\text { Dasar }\end{array}$ & $\begin{array}{c}\text { Konteks dengan Kearifan Loka } \\
\text { maupun Modern }\end{array}$ \\
\hline $\mathrm{I}$ & $\begin{array}{l}\text { Gaya, momen gaya, } \\
\text { kesetimbangan } \\
\text { gaya- }\end{array}$ & \\
\hline 2 & $\begin{array}{l}\text { Gaya, momen } \\
\text { gaya,kesetimbangan } \\
\text { gaya-gaya }\end{array}$ & \\
\hline 3 & $\begin{array}{l}\text { Gaya, momen gaya, } \\
\text { kesetimbangan gaya- } \\
\text { gaya }\end{array}$ & \\
\hline 4 & $\begin{array}{l}\text { Gaya, momen gaya, } \\
\text { kesetimbangan gaya- } \\
\text { gaya }\end{array}$ & \\
\hline 5 & $\begin{array}{l}\text { Gaya, momen gaya, } \\
\text { kesetimbangan gaya- } \\
\text { gaya }\end{array}$ & \\
\hline
\end{tabular}

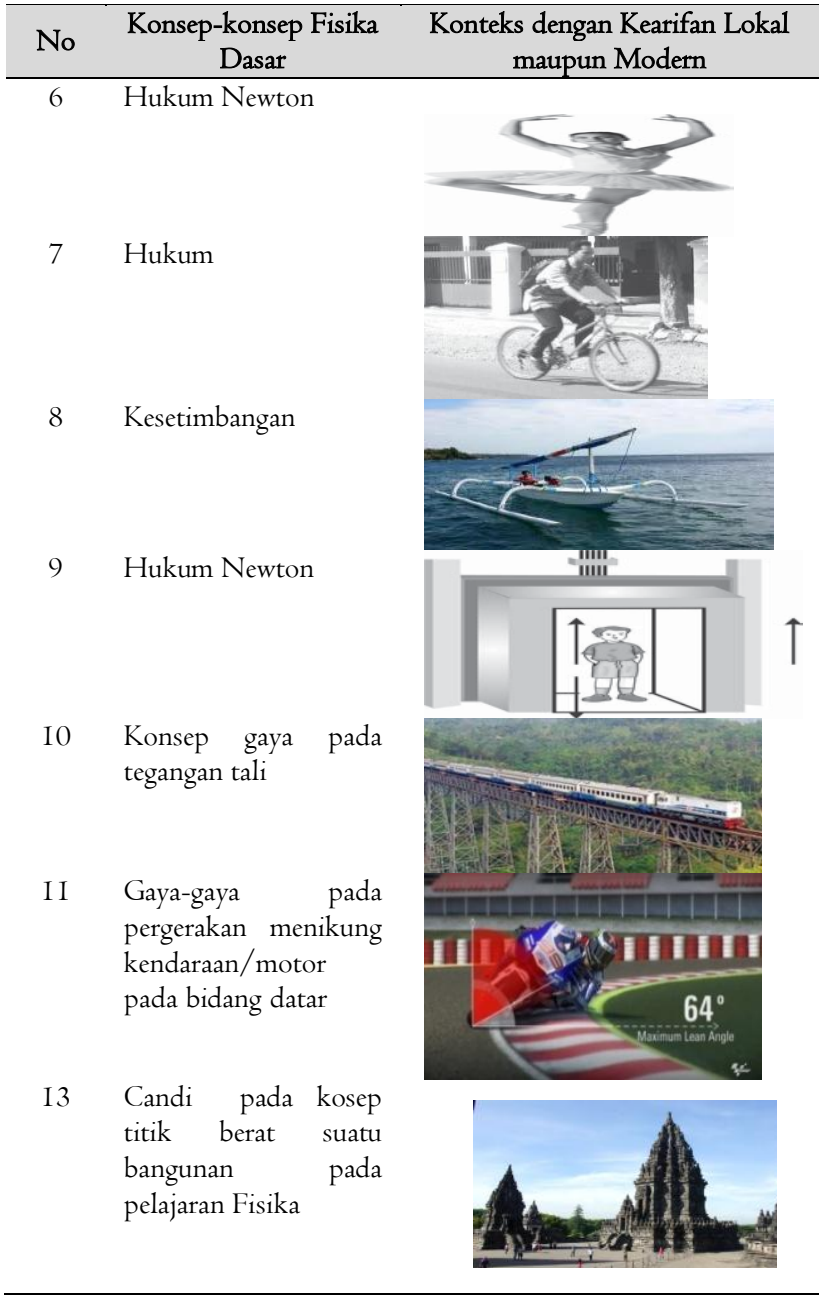

\section{Uraian dan Pembahasan}

Salah satu contoh konsep fisika dan seni dibawah ini adalah uraian dan pembahasan tentang gerakan penari balet yang dapat menyuguhkan nilai-nilai seni dan budaya yang tinggi dan secara tidak langsung erat kaitannya dengan hukum-hukum fisika, antara lain:

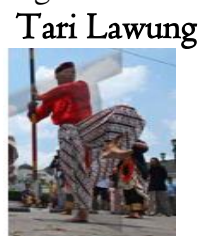

Pada tari lawung dimana seorang penari sedang mengangkat kaki dan tombaknya akan terjadi keseimbangan gaya-gaya, sehingga penari tersebu tidak jatuh, Keseimbangan terjadi antara gayagaya ke atas dan gagaya ke bawah.

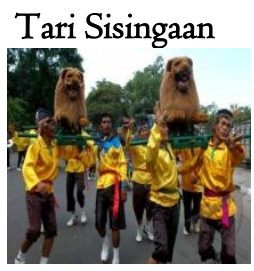

Seni tari Sisingaan merupakan seni budaya daerah Jawa Barat. Tari sisingaan ini terdiri dari empat orang yang memikul patung seekor singa diantara empat orang tersebut. 
Dalam hal ini berat patung singa akan terbagi menjadi empat dan tertumpu pada pundak empat orang, sehingga keempat tersebut menerima beban yang cukup ringan.

\section{Gerak Penari Balet}

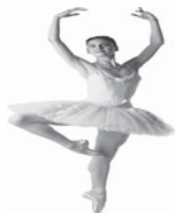

Pada bulan April 1999 diadakan pertemuan fisika terbesar abad 20 bertempat di World Conggress, Atlanta, AS. Tema seminar yang menjadi pusat perhatian banyak pengunjung adalah Physics of Dance.

Dalam seminar ini membahas penerapan hukum fisika pada gerakan balet yang menghasilkan sesuatu yang berguna, mengejutkan, dan mendorong orang lebih menghargai balet. Sebagian besar gerakan tarian balet menerapkan hukum kelembaman.

\section{Bergerak}

Ketika penari sedang bergerak ke depan, bisakah ia membelok atau bergerak melingkar? Menurut Newton, benda yang bergerak lurus akan membelok jika ada gaya ke samping. Bagaimana memperoleh gaya ke samping? Seorang balerina mengetahui cara memperoleh gaya ke samping. Ketika balerina akan membelok ke kanan, kakinya akan menekan lantai ke kiri. Lantai akan memberikan reaksi dan menekan balerina ke kanan sehingga lintasannya berbelok ke kanan. Makin keras balerina menekan lantai, makin tajam belokannya.

\section{Melompat}

Jika ingin mendapatkan lompatan yang lebih tinggi, maka pada saat melompat lututnya ditekuk. Di sini tekukan lutut bertindak seperti pegas yang tertekan, siap melontarkan benda yang menekannya.

\section{Berputar}

Untuk melakukan gerak berputar, balerina menggerakkan ujung sepatu depan dan belakang ke samping berlawanan. Lantai akan memberikan reaksi dengan memberikan gaya yang berlawanan pada kedua ujung sepatu. Ketika sudah berputar, balerina dapat mengatur kecepatan putarnya dengan memperkecil atau melebarkan lengan tangannya untuk mengatur besar momen kelembamannya.

\section{Tanggapan Siswa}

Tabulasi pernyataan dari 75 siswa untuk semua kelas dari kelas 7 sd 12 tentang pemanfaatan Seni dan Budaya dalam pembelajaran Fisika. Proporsi pernyataan siswa pemanfaatan Seni dan Budaya dalam pembelajaran Fisika menjadi sangat menyenangkan dari 26 pernyataan tersebut diatas adalah sebagai berikut;
Tabel 2. Pernyataan Siswa Pemanfaatan Seni dan budaya dalam Pembelajaran Fisika

\begin{tabular}{|c|c|c|c|c|}
\hline No & Pernyataan & $\mathrm{Ya}$ & $\begin{array}{l}\text { Ti- } \\
\text { dak }\end{array}$ & $\begin{array}{l}\text { Ra- } \\
\text { gu }\end{array}$ \\
\hline $\mathrm{I}$ & Fisika itu sangat sulit. & & 2 & \\
\hline 2 & Fisika sangat membosankan. & & 2 & \\
\hline 3 & Fisika sangat banyak hitungannya & I & 4 & \\
\hline 4 & $\begin{array}{l}\text { Fisika bukunya tidak menarik untuk } \\
\text { dipelajari }\end{array}$ & I & 2 & \\
\hline 5 & Fisika sangat membingungkan. & & 2 & \\
\hline 6 & Fisika diperlukan penalaran. & $\mathrm{I}$ & 4 & \\
\hline 7 & Fisika harus pintar berhitung. & I & 4 & \\
\hline 8 & Fisika gurunya rata-rata jahat. & & 2 & $\mathrm{I}$ \\
\hline 9 & Fisika gurunya tidak bisa senyum. & I & I & \\
\hline IO & Fisika tidak menyenangkan & & 4 & I \\
\hline II & Fisika diperlukan praktikum dilab. & I & 3 & \\
\hline $\mathrm{I} 2$ & Fisika sangat menakutkan. & & 2 & \\
\hline $\mathrm{I} 3$ & Fisika belajar tidak santai. & & 2 & \\
\hline $\mathrm{I} 4$ & Fisika sangat menegangkan. & & 6 & I \\
\hline I5 & Fisika itu tidak berguna. & & 2 & \\
\hline 16 & Fisika sebaiknya tidak ikut Ebtanas. & & $\mathrm{I}$ & \\
\hline 17 & Fisika perlu imajinasi & I & I & \\
\hline I8 & Fisika membuat malas berpikir & & 2 & \\
\hline 19 & Fisika pelajaran aneh & & 2 & \\
\hline 20 & Fisika merusak fisik & & 3 & \\
\hline $2 \mathrm{I}$ & Fisika hanya untuk IQ tinggi & I & $\mathrm{I}$ & \\
\hline 22 & Fisika gurunya harus menyenangkan & & 2 & \\
\hline 23 & $\begin{array}{l}\text { Fisika gurunya harus kreatif dan } \\
\text { inovatif }\end{array}$ & & 2 & \\
\hline 24 & $\begin{array}{l}\text { Fisika gurunya harus mengerti } \\
\text { kesulitan siswa }\end{array}$ & & 2 & \\
\hline 25 & $\begin{array}{l}\text { Fisika gurunya harus seorang } \\
\text { motivator }\end{array}$ & & 3 & \\
\hline 26 & Fisika itu harus mudah dipelajari. & & 3 & \\
\hline & Total & 8 & 64 & 3 \\
\hline & Prosentase & II & 85 & 4 \\
\hline
\end{tabular}

I. Proporsi menjadikan siswa belajar fisika sangat menyenangkan sebesar $85 \%$

2. Proporsi menjadikan siswa belajar fisika tidak menyenangkan sebesar II \%

3. Proporsi menjadikan siswa belajar fisika masih meragukan sebesar $4 \%$

Dari tabulasi pernyataan siswa tersebut diatas pemanfaatan seni dan budaya atau indiginasi seni dan budaya sangat membantu siswa untuk membuka atau mengawali pemberian pelajaran Fisika dengan baik dan sangat menyenangkan. Angka-angka tersebut diatas memberikan jalan bagi para guru Fisika untuk banyak berinovasi dalam pembelajaran Fisika disekolah sehingga mampu memberikan perubahan-perubahan yang cukup signifikan dan diterima serta disenangi oleh siswa.

\section{Kesimpulan}

Dari beberapa peragaan yang terdapat dalam tabulasi beberapa konsep IPA-fisika yang terdiri dari konsep;
I. Gaya
5. Titik berat
2. Listrik magnet
6. Gerak melingkar
3. Cahaya
7. Kelembaman
4. Kekekalan energy 
Ternyata belajar fisika sangat menarik dan mudah untuk dipelajari, serta dapat memotivasi siswa menjadi sangat menyenangkan jika pada proses pembelajaran IPA-fisika nilai-nilai seni dan budaya dilibatkan di dalamnya, atau meng-Indiginasikan Seni dan Budaya dalam pembelajaran Fisika.

\section{Kepustakaan}

Ali Nugraha, A.Sy. Dina Dwiyana. (2010). Dasar-dasar Matematika dan Sains. Jakarta: Universitas Terbuka

Dash, V.B. 1980. Basic Principle of Ayurveda. New Delhi: Concept Publ.Co.

Dash, V.B. 1980. Diagnosis and Treatment of Diseases in Ayurveda. New Delhi: Concept

Hallyday, D. \& Resnick, R. (2005). Fisika jilid I edisi ketiga. Jakarta: Erlangga

IPP.(2013).Pengertian Dan Definisi Seni budaya Menurut Para Ahli. I3 Otober, 2013.

https://www.facebook.com/permalink.php?id $=45264159$ 48547798story_fbid $=4526547$ II 520134 . ditampilkan pada tanggal I4 Nov 2015 02:23:07 GMT.

Karyadi, B. (1999). Peningkatan mutu pelajaran sains dan matematika melalui upaya indiginasi seni budaya. Makalah disajikan pada National Workshop on Integration of Values of Art into ScienceTeaching, Surakarta. Desember 1999.

Mujadi,dkk, (20I I). Fisika Dasar I, Jakarta: Universitas Terbuka Muhibbin Syah, (20I3). Psikologi Belajar. Raja Grafindo Persada

Primadi, T. (1998). Proses kreasi, apresiasi, belajar. Bandung: ITB.

Pusposutardjo, S. (1999). Indiginasi nilai-nilai seni dalam pembelajaran ilmu-ilmu matematika dan pengetahuan alam sebagai bagian dari proses pembudayaan peserta didik.

Makalah disajikan pada National Workshop on Integration of Values of Art into Science Teaching, Surakarta. Desember 1999.

Rai. Godagama, S.I 996. The Hand Book of Ayurveda. London: K-yle Katie.

Miftah Ridwan. M. (2013).Macam-macam Teori Belajar. I4 Mei 2013. http://miftahridwan.blogspot.com/2013/05/macammacam-teori-belajar.html. ditampilkan pada tanggal $15 \mathrm{Nov}$ 2015 08:00:34 GMT

Nur Taufik. (2015).Pengertian Seni Menurut Ki hajar Dewantara Dan Para Ahli . 4 Agt 2015.

http://www.dinamikabelajar.com/2015/08/pengertian-senimenurut-ki-hajar.html. ditampilkan pada tanggal I3 Nov 2015 17:47:00 GMT.

Seputar Pengetahuan.(2015). Pengertian Budaya Menurut Para Ahli Lengkap. Maret 07, 2015

http://www.seputarpengetahuan.com/2015/03/pengertianbudaya-menurut-para-ahli.html. ditampilkan pada tanggal I5 Nov 2015 23:27:26 GMT.

Supriyono,K.H. (2003). Common textbook (edisi revisi) strategi pembelajaran fisika. Malang: FMIPA Universitas Malang.

Tim Penulisan Naskah Pengembangan Media Kebudayan.(1977). Sejarah Seni Budaya Jawa Barat II. Kantor Wilayah Pendidikan dan Kebudayaan Propinsi Jabar Kota, Jakarta, 